\title{
PENERAPAN SISTEM PENGENDALIAN INTERN TERHADAP PEMBERIAN KREDIT PADA PT PEGADAIAN (PERSERO) UNIT PELAYANAN CABANG KALIWUNGU
}

\author{
Arini Amalia Rahma dan Siti Mutmainah, S.E., M.Si., Akt. \\ Jurusan Akuntansi, Politeknik Negeri Semarang Jl Prof Sudharto SH Tembalang \\ Semarang \\ Imut.polines@yahoo.co.id
}

\begin{abstract}
Internal control is a process carried out by the company to provide adequate guarantees for achieving control objectives. The objective of this Research is to find out the current internal control system that is applied at PT Pegadaian (Persero) Kaliwungu Branch Service in the process of granting credit. The next objective is to identify whether the components of internal control applied are according to COSO. The data used are qualitative data, primary data, and secondary data. The methods of collecting data are interview, observation, and questionnaire. For writing the Research uses descriptive and exposition methods. There are five components of internal control according to the Committee of Sponsoring Organization (COSO), they are Control Environment, Risk Assessment, Control Activities, Information and Communication, and Monitoring. The results of the discussion in the Research shows that the application of the internal control system for granting credit at PT Pegadaian (Persero) Kaliwungu Branch Service is in accordance with COSO internal control component, but the Control Environment and Control Activities has not been fully implemented.
\end{abstract}

Keywords: Internal Control, Component Control, Granting Credit.

\begin{abstract}
ABSTRAK:Pengendalian intern merupakan suatu proses yang dijalankan oleh perusahaan untuk memberikan jaminan yang memadai atas tercapainya tujuan pengendalian. Tujuan penelitian ini adalah untuk mengetahui sistem pengendalian intern saat ini yang diterapkan pada PT Pegadaian (Persero) Unit Pelayanan Cabang Kaliwungu dalam proses pemberian kredit. Tujuan berikutnya yaitu untuk melakukan identifikasi terhadap komponen pengendalian intern yang diterapkan tersebut apakah disusun sesuai dengan komponen sistem pengendalian intern menurut COSO. Data yang digunakan antara lain data kualitatif, data primer, dan data sekunder. Metode pengumpulan data dari penelitian ini menggunakan metode wawancara, observasi, dan kuesioner. Penulisan penelitian menggunakan metode deskriptif dan eksposisi. Terdapat lima komponen pengendalian intern menurut Committee of Sponsoring Organization (COSO) yaitu Lingkungan Pengendalian, Penilaian Risiko, Aktivitas Pengendalian, Informasi dan Komunikasi, serta Pemantauan. Dari hasil pembahasan penelitian menunjukkan bahwa penerapan sistem pengendalian intern terhadap pemberian kredit pada PT Pegadaian (Persero) Unit Pelayanan Cabang Kaliwungu telah sesuai dengan komponen pengendalian intern COSO, namun Lingkungan Pengendalian dan Aktivitas Pengendalian belum sepenuhnya dijalankan.
\end{abstract}

Kata Kunci: Pengendalian Intern, Komponen Pengendalian, Pemberian Kredit. 


\section{PENDAHULUAN}

Perubahan iklim ekonomi global memiliki dampak yang luas terhadap perekonomian bangsa Indonesia. Sebagai negara berkembang, Indonesia harus senantiasa menciptakan perubahan-perubahan positif untuk meningkatkan kemajuan bangsa. Ada sejumlah tantangan yang harus diselesaikan bangsa Indonesia guna memastikan pertumbuhan ekonomi yang berkelanjutan dan inklusif. Tantangan tersebut antara lain bagaimana menciptakan kondisi yang dapat menjamin generasi mendatang mendapatkan kesempatan hidup yang lebih baik (Kompas.com, 2018). Oleh karena itu pemerintah harus menyadari pentingnya mengambil kebijakan terbaik untuk meningkatkan ketahanan atas berkembangnya peningkatan risiko global. Salah satu upaya untuk meningkatkan ketahanan bangsa adalah senantiasa melakukan pembangunan nasional.

Pada dasarnya pembangunan nasional adalah upaya untuk memenuhi keadilan rakyat Indonesia. Pelaksanaan pembangunan nasional mencakup semua aspek kehidupan bangsa. Badan Usaha Milik Negara (BUMN) sebagai agen pembangunan memiliki peran penting dalam pembangunan bangsa Indonesia. Pegadaian sebagai bagian dari BUMN didirikan untuk membantu meningkatkan kesejahteraan rakyat kecil dan mendukung program pemerintah dalam pembangunan nasional di bidang ekonomi.

Pegadaian adalah satu-satunya badan usaha di Indonesia yang secara resmi mempunyai izin untuk melaksanakan kegiatan lembaga keuangan berupa pembiayaan dalam bentuk penyaluran dana ke masyarakat atas dasar hukum gadai. Komitmen Pegadaian pada upaya peningkatan kesejahteraan masyarakat dibuktikan dengan konsistensi perusahaan melayani masyarakat menengah ke bawah. Produk dan layanan yang ditawarkan menjadi solusi tepat bagi masyarakat dalam memenuhi kebutuhan finansialnya.

Bisnis Pegadaian dilaksanakan dengan mengusung tiga bidang inti layanan, yakni pembiayaan, bisnis emas, dan aneka jasa. Kredit merupakan salah satu produk dan layanan yang ditawarkan PT Pegadaian dalam bidang pembiayaan. Dalam menjalankan sistem pemberian kredit perlu dilakukan pengawasan yang baik agar tidak timbul masalah di kemudian hari.

Produk utama PT Pegadaian dalam bidang pembiayaan antara lain, Kredit Cepat Aman (KCA), Kredit Gadai Sistem Angsuran (KRASIDA), Kredit Mikro Pegadaian (KREASI). Kredit dilakukan atas dasar hukum gadai, dalam hal ini nasabah yang ingin mengajukan pinjaman kepada PT Pegadaian wajib menyerahkan barangnya untuk dijadikan jaminan sebagai persyaratan dalam pemberian kredit. Pelunasan pinjaman tersebut dapat dilakukan sesuai dengan jangka waktu yang telah ditentukan. Dengan adanya produk dan layanan yang dihadirkan Pegadaian, dapat mempermudah mayarakat untuk mendapatkan dana tunai secara cepat, mudah, dan juga aman tanpa harus menjual barang berharga yang dimiliki.

PT Pegadaian (Persero) Unit Pelayanan Cabang Kaliwungu, atau biasa disebut dengan Pegadaian UPC Kaliwungu adalah Unit Pegadaian yang bertempat di Jalan Raya Kaliwungu Kendal. Pegadaian UPC Kaliwungu juga menyediakan produk dan layanan dalam bidang pembiayaan, bisnis emas, dan aneka jasa lainnya. Dalam bidang pembiayaan Pegadaian UPC Kaliwungu juga menawarkan berbagai macam kredit, namun 
pembahasan kali ini akan menitiberatkan pada produk Kredit Cepat Aman (KCA), karena pemberian kredit tersebut merupakan transaksi yang sering terjadi pada perusahaan, sehingga memiliki risiko yang tinggi, dan harus dilakukan pengawasan yang tepat dan ketat. Risiko yang terjadi seperti timbulnya kredit macet, adanya permasalahan pada barang jaminan nasabah, dan risiko-risiko lainya yang dapat mengganggu aktivitas gadai KCA.

Keberadaan Pegadaian sangat berperan ditengah masyarakat, terlebih lagi terhadap masyarakat menengah kebawah. Pegadaian menawarkan kredit dengan persyaratan yang terbilang mudah dan ringan. Hal ini tentu saja mempermudah masyarakat untuk mencapai kesejahteraannya di bidang ekonomi. Dalam melaksanakan pemberian kredit harus dilakukan sesuai dengan prosedur yang berlaku pada PT Pegadaian. Sistem pengendalian intern memberikan keyakinan memadai dalam pencapaian keandalan informasi keuangan, kepatuhan terhadap hukum dan peraturan yang berlaku, serta efektivitas dan efisiensi operasi. Selain itu dengan adanya sistem pengendalian intern dapat digunakan untuk mencegah terjadinya hal-hal yang tidak diinginkan, dan melacak berbagai kesalahan yang terjadi sehingga dapat dilakukan evaluasi yang tepat.

Oleh karena itu dalam menjalankan sistem pemberian kredit, PT Pegadaian juga perlu menerapkan sistem pengendalian intern yang baik. Bahkan Setiap kegiatan proses operasional unit kerja di Pegadaian harus berpedoman pada standar operasi prosedur kerja yang didalamnya telah melekat sistem pengendalian intern yang memadai. Seluruh manajemen dan karyawan Pegadaian memiliki peran dan tanggung jawab dalam meningkatkan kualitas dan pelaksanaan sistem pengendalian intern.

\section{Rumusan Masalah}

Berdasarkan latar belakang masalah yang sudah dipaparkan di atas, maka peneliti mengidentifikasi permasalahan dalam Penelitian mengenai sistem pengendalian intern terhadap pemberian kredit tahun 2019 yaitu:

a. Bagaimana penerapan sistem pengendalian intern terhadap pemberian kredit pada PT Pegadaian (Persero) Unit Pelayanan Cabang Kaliwungu?

b. Apakah sistem pengendalian intern yang diterapkan perusahaan telah sesuai dengan model pengendalian intern Committee of Sponsoring Organization (COSO)?

\section{METODE}

Metode merupakan cara yang tepat untuk melakukan sesuatu. Sedangkan penelitian adalah suatu kegiatan untuk mencari, mencatat, merumuskan dan menganalisis sampai menyusun laporannya (Narbuko \& Achmadi, 2008:1). Fungsi penelitian adalah mencarikan penjelasan dan jawaban terhadap permasalahan serta memberikan alternatif bagi kemungkinan yang dapat digunakan untuk pemecahan masalah.

Metode penelitian menurut Sugiyono (2007:2) merupakan cara ilmiah untuk mendapatkan data dengan tujuan dan kegunaan tertentu. Metode penelitian yang digunakan meliputi klasifikasi data, metode pengumpulan data, metode analisis data, serta metode penulisan.

\section{Klasifikasi Data Menurut Sifatnya}

Data memiliki beberapa ciri yang dapat diklasifikasikan menurut kekhususan tertentu, sesuai dengan maksud peneliti ataupun sumber data yang digunakan. Data kualitatif diungkapkan dalam bentuk kalimat serta uraian-uraian, bahkan dapat berupa cerita pendek (Bungin, 2013: 124).

Dalam Penelitian ini, peneliti hanya menggunakan data yang 
bersifat kualitatif. Data kualitatif yang digunakan dalam penulisan Penelitian ini meliputi gambaran umum PT Pegadaian (Persero) Unit Pelayanan Cabang Kaliwungu seperti sejarah, visi-misi, budaya perusahaan, struktur organisasi beserta uraian tugas, aktivitas pemberian kredit, khususnya Gadai Kredit Cepat Aman atau Gadai KCA, kuesioner sistem pengendalian intern terhadap pemberian kredit, hasil wawancara dan checklist observasi yang telah dilakukan pada PT Pegadaian (Persero) Unit Pelayanan Cabang Kaliwungu.

\section{Klasifikasi Data Menurut Sumbernya}

Jenis data menurut sumbernya dapat digolongkan menjadi dua yaitu:

\section{a. Data Primer \\ Menurut Saifuddin Azwar} (2010:91) data primer atau data tangan pertama adalah data yang diperoleh langsung dari subjek penelitian dengan mengenakan alat pengukuran atau alat pengambilan data langsung pada subjek sebagai sumber informasi yang yang dicari. Data primer biasanya diperoleh melalui observasi yang bersifat langsung sehingga akurasinya lebih tinggi. Data primer yang digunakan dalam Penelitian ini berupa jawaban dari kuisioner pengendalian intern yang telah dibagikan kepada karyawan perusahaan seperti kasir, penyimpan, dan karyawan BPO. Selain kuesioner yaitu wawancara, dan observasi tentang pemberian kredit pada Pegadaian UPC Kaliwungu.

b. Data Sekunder

$$
\text { Saifuddin Azwar (2010:91) }
$$

menyebutkan bahwa data sekunder atau data tangan kedua adalah data yang diperoleh lewat pihak lain, tidak langsung diperoleh oleh peneliti dari subjek penelitiannya. Data sekunder biasanya berwujud data dokumentasi atau data laporan yang telah tersedia. Adapun data sekunder dalam penelitian ini meliputi gambaran umum dari PT Pegadaian (Persero) Unit Pelayanan Cabang Kaliwungu termasuk di dalamnya sejarah, visi misi, struktur organisasi beserta uraian tugas, dan dokumen-dokumen pemberian kredit.

\section{Metode Pengumpulan Data}

Dalam Penelitian ini dibutuhkan data pendukung yang diperoleh dengan suatu metode tertentu. Metode yang digunakan dalam penyusunan penelitian ini antara lain:

a. Wawancara

Menurut Esterberg (dalam Sugiyono, 2014:72) wawancara merupakan pertemuan dua orang untuk bertukar informasi dan ide melalui tanya jawab, sehingga dapat dikontruksikan makna dalam suatu topik tertentu. Wawancara dilaksanakan secara langsung dengan Pengelola Pegadaian Unit Pelayanan Cabang Kaliwungu beserta karyawan mengenai kegiatan operasional perusahaan beserta sistem pemberian kredit yang diterapkan perusahaan, khususnya pada Kredit Cepat Aman (KCA).

\section{b. Observasi}

Observasi atau pengamatan adalah alat pengumpulan data yang dilakukan cara mengamati dan mencatat secara sistematik gejalagejala yang diselidiki (Narbuko \& Ahmadi, 2008:70). Observasi dilakukan untuk mengetahui sistem pengendalian intern pada pemberian kredit gadai KCA yang diterapkan PT Pegadaian (Persero) Unit Pelayanan Cabang Kaliwungu, dengan mengamati kegiatan yang dilakukan perusahaan, serta menelusuri dokumen, catatan, dan prosedur yang diterapkan perusahaan.

c. Kuesioner

Menurut Sugiyono (2007:142) kuesioner merupakan teknik pengumpulan data yang dilakukan dengan cara memberi seperangkat pertanyaan atau pernyataan tertulis kepada responden untuk dijawabnya. Dalam Penelitian ini dibagikan kuesioner kepada karyawan PT Pegadaian (Persero) Unit Pelayanan 
Cabang Kaliwungu. Kuesioner tersebut mengenai sistem pengendalian intern pada pemberian kredit gadai KCA yang diterapkan perusahaan.

\section{Metode Penulisan}

Dalam Penelitian ini metode penulisan yang akan digunakan adalah sebagai berikut:

a. Metode Deskriptif

Menurut Alek dan Achmad (2011:184) metode deskriptif adalah metode yang berfungsi untuk mendeskripsikan atau menggambarkan bentuk objek pengamatan. Dalam Penelitian ini metode deskriptif digunakan untuk menguraikan gambaran umum PT Pegadaian (Persero) Unit Pelayanan Cabang Kaliwungu, seperti sejarah dan latar belakang Pegadaian, budaya perusahaan, visi-misi, struktur organisasi, maupun tugas dan wewenang setiap bagian. Selain itu metode deskriptif digunakan untuk menjelaskan desain atau rancangan sistem pengendalian intern yang diterapkan dan dijalankan, terkait pemberian kredit gadai KCA.

b. Metode Eksposisi

Alek dan Achmad (2011: 183) mengemukakan bahwa metode eksposisi adalah penulisan yang bertujuan memberikan informasi, penjelasan, keterangan atau pemahaman. Dengan metode ini dapat digunakan untuk menjelaskan tentang prosedur pemberian kredit gadai KCA maupun sistem pengendalian intern yang berlaku, dan melakukan identifikasi kesesuaian tentang elemen pengendalian yang diterapkan dan dijalankan tersebut dengan elemen pengendalian intern menurut COSO.

\section{HASIL DAN PEMBAHASAN}

\section{Sistem Pengeluaran Kas}

Sistem pengeluaran kas pada pemberian kredit di PT Pegadaian (Persero) Unit Pelayanan Cabang
Kaliwungu akan dijelaskan sebagai berikut:

\section{a. Dokumen yang Digunakan}

Berdasarkan hasil pengamatan dan wawancara, dokumen-dokumen yang digunakan terkait pemberian kredit pada PT Pegadaian (Persero) Unit Pelayanan Cabang Kaliwungu adalah sebagai berikut:

1. Formulir Pengajuan Kredit (FPK)

Formulir Pengajuan Kredit adalah dokumen yang digunakan nasabah untuk pengajuan kredit. Dokumen ini memiliki 2 bagian, yaitu bagian depan dan belakang. Bagian depan berisi data nasabah seperti nama, alamat, barang jaminan, nomer telepon, dan data lainnya. Pada bagian belakang berisi uraian barang jaminan dan hasil pengujian, bagian ini terdapat taksiran dan maksimal uang pinjaman yang akan diberikan oleh nasabah yang meminjam dana. Formulir Pengajuan Kredit harus dilampiri oleh fotokopi identitas diri nasabah seperti KTP atau SIM yang masih berlaku.

\section{Surat Bukti Gadai (SBG)}

Surat Bukti Gadai adalah dokumen yang diberikan kepada nasabah saat nasabah menyetujui jumlah pinjaman yang diberikan. SBG memiliki 2 lembar, lembar pertama akan diberikan kepada nasabah saat pencairan dana, lembar kedua atau yang disebut dengan dwilipat, akan disimpan oleh pihak Pegadaian sebagai arsip. Didalam SBG akan tertera barang jaminan dan spesifikasinya, kolom tanda tangan nasabah dan petugas Pegadaian, identitas nasabah, taksiran dan jumlah uang pinjaman, tanggal kredit dan tanggal jatuh tempo, syarat dan ketentuan kredit, beserta perjanjian utang piutang. Apabila SBG hilang maka nasabah harus mengurus surat kehilangan SBG di Kepolisian dan selanjutnya pihak Pegadaian akan mencetak SBG baru.

3. Kitir

Kitir sebenarnya adalah kesatuan dari Formulir Pengajuan Kredit, kitir 
akan dipotong untuk diberikan kepada nasabah agar dapat mencairkan uang pinjaman di loket kasir. Selain itu kitir juga berasal dari satu kesatuan SBG yang berada pada dwilipat (lembar kedua SBG). Kitir dari SBG akan dipotong untuk nantinya disatukan dengan FPK, fotokopi identitas, dan barang jaminan ke dalam suatu plastik agar memudahkan saat pencarian barang jaminan yang sudah disimpan ke dalam gudang penyimpanan.

\section{Nota Transaksi}

Dokumen ini akan diberikan kepada nasabah ketika melakukan pencairan kredit di loket kasir. Nota juga diberikan kepada nasabah ketika akan melakukan pembayaran, seperti cicilan ataupun pelunasan.

\section{b. Catatan Akuntansi}

Berdasarkan hasil wawancara dan pengamatan (observasi) yang dilakukan terhadap dokumen dan catatan sistem pemberian kredit, catatan akuntansi yang berkaitan dengan gadai KCA pada PT Pegadaian (Persero) Unit Pelayanan Cabang Kaliwungu antara lain:

1. Rekapitulasi Transaksi Kasir

Rekapitulasi transaksi kasir merupakan catatan yang dipakai untuk mencatat transaksi harian perusahaan, yang diotorisasi oleh kasir dan pengelola Unit Pelayanan Cabang. Catatan ini berfungsi untuk menjelaskan berapa kali setiap transaksi dilakukan, beserta berapa nilai pengeluaran atau penerimaan perusahaan dari transaksi-transaksi tersebut. Adapun jenis transaksi yang terjadi seperti pencairan gadai, ambil modal, setor modal, pelunasan gadai tebus, pelunasan gadai cicil, pelunasan gadai ulang, pelunasan gadai lelang, dan transaksi lainnya.

\section{Rekening Koran}

Rekening koran merupakan catatan yang dipakai untuk mencatat transaksi keuangan secara menyeluruh dari suatu rekening milik perusahaan. Fungsi rekening koran yaitu menampilkan transaksi yang terjadi selama kurun waktu tertentu, dalam hal ini perusahaan mencatat perharinya, rekening koran juga berfungsi untuk melakukan rekap daftar keuangan, baik transaksi arus masuk dan keluar. Informasi yang terdapat di rekening koran mengenai jumlah saldo awal, saldo akhir, mutasi debet dan mutasi kredit, beserta keterangan setiap transaksinya.

Rekening koran yang dimiliki perusahaan berbentuk rekening koran kas besar dan rekening koran kas kecil. Rekening koran kas besar memuat keterangan seperti saldo awal, ambil modal pagi hari, setor modal sore hari. Pada rekening koran kas kecil berisi jumlah saldo awal, rincian setiap transaksi seperti pelunasan gadai ulang, pelunasan gadai tebus, pencaran gadai, dan transaksi-transaksi lainnya.

\section{c. Bagian dan Fungsi yang Terkait}

Bagian dan fungsi yang terkait dalam sistem pengeluaran kas pada pemberian kredit gadai KCA di PT Pegadaian (Persero) Unit Pelayanan Cabang Kaliwungu adalah sebagai berikut:

1. Penaksir

Dalam sistem pemberian kredit bagian ini bertugas untuk menaksir barang jaminan yang diberikan nasabah sebagai agunan untuk mendapatkan kredit. Namun tugas penaksir dirangkap oleh pengelola UPC karena keterbatasan SDM perusahaan dibagian penaksir dan petugas administrasi. Dengan keterbatasan yang dimiliki, rangkap jabatan ini masih bisa dikendalikan karena perusahaan memiliki karyawan BPO yang dapat membantu tugas dari penaksir.

Dalam menentukan besarnya taksiran dan uang pinjaman (UP), penaksir harus mengikuti aturan yang sudah berlaku dan di tetapkan oleh Direksi PT Pegadaian (Persero). Taksiran menggunakan Standar Taksiran Logam (STL). Untuk menjadi penaksir terlebih dahulu akan dibekali dengan diklat dan pelatihan yang dilakukan perusahaan. 
2. Pengelola UPC

Pengelola UPC bertugas untuk mengotorisasi dokumen-dokumen yang berkaitan dengan pemberian gadai KCA, seperti Surat Bukti Gadai.

\section{Kasir}

Kasir memiliki tugas dalam hal mencairkan jumlah uang pinjaman yang sudah ditetapkan sebelumnya, serta bertugas menerima uang dari nasabah ketika terjadi transaksi pelunasan. Transaksi pengeluaran dan penerimaan uang sekaligus ditangani oleh bagian kasir yang hanya dijabat oleh satu orang saja. Hal ini terjadi karena perusahaan memiliki keterbatasan SDM, namun setiap kegiatan yang dilakukan oleh Kasir selalu diawasi dan diotorisasi oleh Pengelola UPC, sehingga ada pengendalian dan pengawasan yang ketat dari pihak atasan. Disamping itu tugas kasir dalam hal pengeluaran dan penerimaan uang saat pelunasan, juga dilakukan sebagai bentuk efisiensi kerja.

\section{Penyimpan}

Penyimpan bertugas untuk mengecek dokumen dan barang jaminan yang digunakan nasabah dalam mengajukan gadai KCA, dan menyimpannya ke dalam gudang. Selain itu penyimpan bertugas untuk mengecek kondisi gudang beserta barang-barang yang ada didalamnya.

\section{Perolehan Pemahaman dan} Dokumentasi Hasil Pemahaman atas Pengendalian Intern PT Pegadaian (Persero) Unit Pelayanan Cabang Kaliwungu

Manajemen bertanggung jawab untuk menetapkan dan menyelenggarakan pengendalian intern yang memadai. Pengendalian intern tersebut harus dipahami dan diselenggarakan oleh seluruh komponen dalam perusahaan. Ada tiga cara dalam memperoleh pemahaman yaitu dengan membuat kuesioner pengendalian untuk diberikan kepada bagian-bagian yang terkait seperti kepada bagian kasir, penyimpan, dan perwakilan dari karyawan BPO. Selain kuesioner yaitu menggunakan bagan arus (flowchart), dan deskripsi naratif untuk mendokumentasikan pengendalian intern perusahaan. Pemahaman terhadap pengendalian intern untuk pemberian kredit gadai KCA dilakukan melalui wawancara dan melakukan observasi dengan menelusuri dokumen dan catatan perusahaan.

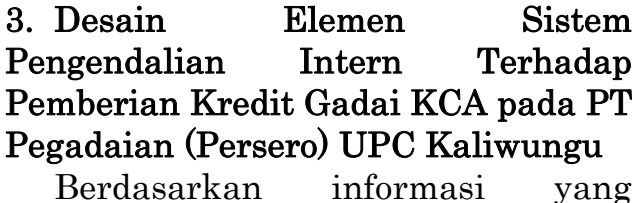
didapatkan melalui observasi dan wawancara yang dilakukan pada Pegadaian UPC Kaliwungu, berikut merupakan lima komponen pengendalian intern menurut COSO (Committee of Sponsoring Organization) terhadap sistem pemberian kredit gadai KCA pada PT Pegadaian (Persero) Unit Pelayanan Cabang Kaliwungu:

a. Lingkungan Pengendalian

Lingkungan pengendalian merupakan landasan untuk semua unsur pengendalian intern, yang membentuk disiplin dan stuktur. Lingkungan pengendalian mencerminkan sikap dan tindakan manajemen mengenai pentingnya pengendalian intern dari PT Pegadaian (Persero) Unit Pelayanan Cabang Kaliwungu. Berikut merupakan subkomponen dari lingkungan pengendalian pada Pegadaian UPC Kaliwungu:

1. Integritas dan nilai-nilai etis

Subkomponen lingkungan pengendalian yang menyangkut integritas dan nilai-nilai etis meliputi tindakan manajemen untuk menghilangkan atau mengurangi dorongan dan godaan yang mungkin membuat karyawan melakukan tindakan tidak jujur, ilegal, atau tidak etis, yang dapat dituangkan melalui pernyataan kebijakan, kode perilaku, dan teladan. Dalam pelaksanannya perusahaan memiliki berbagai 
peraturan dan Standar Etika yang disebut dengan code of conduct. Perusahaan menggunakan Pedoman Operasional Cabang (POC) dalam bekerja. Pedoman operasional untuk semua produk bisnis seperti gadai KCA dan Standar Operasional Prosedur (SOP) lainnya di atur dalam peraturan direksi, instruksi direksi, dan keputusan direksi.

Dengan diterapkannya berbagai peraturan dan kebijakan yang ada dapat membentuk karyawan untuk menjunjung tinggi kejujuran, tanggung jawab, keterbukaan, dan kepedulian. Segala bentuk pelanggaran yang dilakukan karyawan juga akan diberikan sanksi sesuai dengan peraturan yang berlaku, hal itu merupakan bentuk komitmen manajemen agar dapat membentuk sikap positif karyawan. Dengan demikian subkomponen lingkungan pengendalian yang menyangkut integritas dan nila-nilai etis dapat diterapkan dengan baik.

\section{Komitmen pada kompetensi}

Komitmen pada kompetensi meliputi pertimbangan manajemen tentang tingkat kompetensi bagi pekerjaan tertentu, dan bagaimana tingkatan tersebut diterjemahkan menjadi keterampilan dan pengetahuan yang diperlukan Komitmen pada kompetensi PT Pegadaian (Persero) Unit Pelayanan Cabang Kaliwungu dapat dilihat dari proses pengisian sumberdaya perusahaan. Rekrutmen terhadap karyawan dipusatkan pada kantor pusat Pegadaian melalui jalur online dengan persyaratan yang diatur khusus oleh kantor pusat Pegadaian, seperti pendidikan minimal dari jenjang SLTA, dengan rentang usia 18-30 tahun, serta bersedia ditempatkan di seluruh wilayah kerja di Indonesia. Karyawan Pegadaian juga harus melewati proses pendidikan dan latihan agar dapat mengetahui tugas dan tanggung jawab, serta budaya kerja perusahaan.
3. Partisipasi dewan komisaris atau komite audit

Komposisi dewan komisaris dan komite audit serta cara bagaimana mereka melakukan tanggung jawab pengawasan memiliki dampak yang besar terhadap lingkungan pengendalian. PT Pegadaian (Persero) memiliki dewan komisaris yang bertugas melakukan pengawasan secara umum dan/atau khusus sesuai dengan Anggaran Dasar dan memberi nasehat kepada direksi. Keterlibatan dewan komisaris dapat dilihat dari tanggung jawabnya dalam memastikan manajemen telah menerapkan pengendalian intern dan proses pelaporan keuangan yang layak.

Perusahaan juga memiliki komite audit yang bertanggung jawab dalam mengawasi pelaporan keuangan serta melakukan komunikasi yang berkelanjutan dengan auditor. Pegadaian UPC kaliwungu diawasi oleh tim auditor yang diturunkan langsung oleh PT Pegadaian (Persero). Dengan demikian penerapan subkomponen ini telah sesuai dengan COSO, karena adanya partisipasi dari dewan komisaris dan komite audit.

d. Filosofi dan gaya operasi manajemen

Manajemen harus mengambil tindakan aktif untuk menjadi contoh berperilaku etis dengan bertindak sesuai kode etik. Manajemen melalui aktivitasnya, memberikan isyarat yang jelas kepada para karyawan tentang pentingnya pengendalian internal. Filosofi dan gaya operasi Pegadaian UPC Kaliwungu tergambar pada visi misi dan budaya kerja perusahaan, yang merupakan pondasi dan pedoman perusahaan untuk mencapai tujuannya.

Manajemen PT Pegadaian (Persero) memiliki kebijakan dalam pertumbuhan OSL (Out Standing Loan) dan pendapatan perusahaan per tahun, biasanya nilai kenaikan OSL diatas 10\%. Dengan demkian subkomponen filosofi dan gaya operasi manajemen telah sesuai dengan 
COSO, perusahaan telah menerapkan sikap kejujuran, kerjasama, dan gotong royong kepada karyawan. Namun dalam kebijakan pertumbuhan OSL dinilai kurang realistis, bagi perusahaan yang tidak bisa meningkatkan OSL atau pendapatan, akan diberikan teguran. Walaupun begitu Pegadaian UPC Kaliwungu tidak menekan karyawan untuk memanipulasi hasil OSL ataupun pendapatan.

e. Struktur Organisasi

Struktur organisasi perusahaan menentukan garis-garis tanggung jawab dan kewenangan yang ada. Struktur organisasi sangat berpengaruh terhadap kemampuan perusahaan dalam mencapai tujuannya. PT Pegadaian (Persero) memiliki beberapa tingkatan unit kerja. Kantor pusat pegadaian, kantor wilayah, kantor cabang, dan Unit Pelayanan Cabang memiliki bentuk struktur organisasi yang berbedabeda. Meskipun demikian struktur organisasi yang tercipta sudah menggambarkan tugas dan wewenang setiap bagian. Adapun struktur organisasi Pegadaian UPC Kaliwungu terdiri dari pengelola UPC, penaksir, kasir, penyimpan, dan BPO. Namun terjadi rangkap jabatan pada bagian penaksir dengan pengelola UPC, karena terbatasnya SDM Perusahaan.

f. Pembagian wewenang dan pembebanan tanggung jawab

Dengan adanya pembagian wewenang yang jelas, perusahaan akan dapat mengalokasikan berbagai sumber daya yang dimilikinya untuk mencapai tujuan organisasi. Pegadaian UPC Kaliwungu telah menetapkan struktur organisasi yang disertai dengan uraian jabatan, wewenang, dan tanggung jawab. Pada penerapannya terjadi rangkap jabatan pada Pegadaian UPC Kaliwungu karena terbatasnya SDM perusahaan. Meskipun demikian Pegadaian UPC Kaliwungu tetap berusaha bekerja secara efisien serta melayani nasabah dengan sebaik-baiknya. g. Kebijakan dan praktik sumberdaya Efektif tidaknya pengendalian intern akan sangat bergantung kepada kebijakan dan praktik tentang sumberdaya manusia yang dianut, yang akan menentukan apakah personil perusahaan memiliki tingkat integritas yang diharapkan, etika, dan kompetensi. Setiap karyawan Pegadaian UPC Kaliwungu harus melewati proses pendidikan dan latihan atau diklat. Kegiatan pelatihan dimaksudkan untuk membentuk karyawan yang memiliki integritas dan budaya kerja perusahaan. Untuk meningkatkan kesejahteraan karyawan, perusahaan memberikan bonus dan tunjangan. Karyawan Pegadaian UPC Kaliwungu juga sewaktu-waktu dapat mengalami mutasi ke wilayah kerja lain. Penerapan subkomponen ini sudah sesuai dengan COSO.

\section{b. Penilaian Risiko}

Penilaian risiko atas pelaporan keuangan adalah tindakan yang dilakukan manajemen untuk mengidentifikasi dan menganalisis risiko-risiko yang relevan dengan penyusunan laporan keuangan. Risiko-risiko tersebut merupakan suatu masalah yang dapat menimbulkan kerugian bagi perusahaan. Manajemen harus mengidentifikasi faktor dan penyebab dari munculnya berbagai risiko yang ada. Berikut merupakan risiko-risiko yang terjadi pada PT Pegadaian (Persero) Unit Pelayanan Cabang Kaliwungu yang dapat bersumber dari:

1. Bencana alam

Manajemen harus mengidentifikasi paling tidak satu jenis pengendalian untuk mengatasi setiap risiko yang mungkin dihadapi perusahaan. Bencana alam seperti banjir contohnya merupakan risiko yang dapat terjadi pada Pegadaian UPC Kaliwungu, dimana bangunan hanya memiliki satu tingkat menyebabkan perusahaan harus melakukan pengendalian terkait kemungkinan 
terjadinya banjir. Salah satu upaya untuk menanggulangi bencana tersebut adalah memindahkan berkasberkas yang dimiliki perusahaan ketempat penyimpanan yang aman dan tinggi letaknya. Sehingga ada mitigasi dari perusahaan dalam menghadapi bencana alam tersebut.

2. Banyaknya nasabah yang lupa jatuh tempo

Seringkali nasabah lupa tanggal jatuh tempo dan mengakibatkan pembayaran kredit menjadi tertunda. Padahal perusahaan sudah secara jelas mencantumkan tanggal jatuh tempo, tanggal lelang, dan informasi, informasi lainnya di SBG maupun nota transaksi, akan tetapi nasabah tidak membaca informasi-informasi tersebut. Bagian kasir akan kembali memberikan penjelasan ulang ketika proses pencairan dana berlangsung, yaitu dengan meyebutkan kembali jumlah uang pinjaman, tanggal jatuh tempo dan tanggal lelang.

3. Nasabah susah untuk dihubungi Ketika nasabah meminjam sejumlah dana, terkadang berbanding terbalik dengan rasa tanggung jawab untung melunasi utang tersebut. Pihak Pegadaian akan menghubungi nasabah melalui nomor telepon yang diberikan saat mengajukan gadai KCA. Namun seringkali nasabah susah untuk dihubungi, atau menghilang, dan tidak menyelesaikan kewajiban untuk membayar pinjamannya. Hal ini akan menyebabkan terjadinya kredit macet. Untuk menghadapi masalah tersebut, Pegadaian UPC Kaliwungu akan menjual atau melelang barang jaminan yang mereka miliki. Hasil penjualan lelang akan diperhitungkan hasilnya dibandingan dengan kewajiban nasabah yang harus dipenuhi.

4. Nasabah komplain barangnya sudah dilelang

Pegadaian UPC Kaliwungu terkadang mendapat protes dari nasabah ketika barang jaminan yang mereka miliki terlelang. Padahal jauhjauh hari perusahaan memberikan pemberitahuan kepada nasabah, apabila nasabah sudah melewati jatuh tempo dan belum melunasi utangnya, maka barang akan dilelang. Sehingga pihak perusahaan akan memberikan penjelasan kembali kepada nasabah tersebut, dan menunjukkan bukti pemberitahuan yang sudah dikirim sebelumnya, bahwa barangnya akan masuk lelang.

5. Komplain nasabah karena kondisi fisik barang jaminannya

Gadai KCA memiliki persyaratan untuk membawa agunan atau barang jaminan saat ingin mengajukan pinjaman. Salah satu agunan yang diperbolehkan adalah perhiasan emas. Terkadang pihak perusahaan mendapat komplain dari nasabah saat melihat kondisi fisik barangnya yang penyok atau rantas, ketika barang jaminan dikeluarkan dari gudang penyimpanan untuk diserahkan kembali ke nasabah. Padahal kondisi barang jaminan yang rusak merupakan kondisi awal ketika barang jaminan tersebut masuk. Untuk mengantisipasi kejadian tersebut, pihak Pegadaian akan menuliskan kondisi barang jaminan ketika pertama kali masuk di Surat Bukti Gadai (SBG), seperti adanya penyok atau rantas.

\section{c. Aktivitas Pengendalian}

Aktivitas pengendalian yang dilakukan Pegadaian UPC Kaliwungu yaitu:

1. Pemisahan tugas yang memadai

Pemisahan tugas yang diterapkan pada PT Pegadaian (Persero) Unit Pelayanan Cabang Kaliwungu sudah berjalan dengan baik berdasarkan tugas dan wewenangnya masingmasing. Meskipun demikian tugas penaksir dirangkap oleh Pengelola UPC, karena terbatasnya SDM yang dimiliki perusahaan. SOP Pegadaian menjelaskan ketentuan suatu unit atau cabang memiliki penaksir yang terpisah dengan Pengelola UPC apabila nilai OSL (Out Standing Loan) 
suatu unit diatas 10 milyar, maka unit tersebut mendapat jatah penaksir. Pegadaian UPC Kaliwungu memiliki nilai OSL yang melebihi 10 milyar, yaitu sebesar 16 milyar dan seharusnya mendapat jatah penaksir, akan tetapi perusahaan tidak mendapat formasi tersebut.

2. Otorisasi yang tepat atas transaksi dan aktivitas

Pegadaian memiliki otorisasi bertingkat sebelum pencairan uang pinjaman. Otorisasi juga dilakukan terhadap dokumen-dokumen penunjang pemberian kredit, yaitu FPK yang ditandatangani oleh nasabah, SBG juga akan ditandatangani oleh Pengelola UPC dan nasabah. Nota transaksi sebagai bukti pencairan uang juga akan ditandatangani oleh kasir dan nasabah. Penerapan otorisasi pada setiap transaksinya sudah dilakukan perusahaan dengan baik.

3. Dokumen dan catatan yang memadai

Dalam menjalankan aktivitas gadai KCA dokumen dan catatan disiapkan saat transaksi berlangsung. Dokumen-dokumen terkait gadai KCA meliputi FPK, SBG, beserta masingmasing kitirnya, dwilipat dari SBG, dan nota transaksi. Dokumendokumen tersebut bernomor urut, untuk memudahkan pengendalian atas dokumen yang hilang dan sebagai alat bantu untuk mencari dokumen ketika diperlukan di kemudian hari. FPK dan SBG dirancang bolak-balik untuk meminimalisir penggunaan dokumen. Dokumen tersebut juga memuat informasi terkait identitas nasabah, serta ketentuan gadai KCA.

\section{Pengendalian fisik atas aktiva dan catatan}

Barang jaminan yang diserahkan nasabah saat mengajukan kredit KCA merupakan aktiva yang harus dilindungi oleh perusahaan. Barang jaminan tersebut disimpan didalam gudang penyimpanan, dan rutin untuk dicek kondisinya sehingga dapat terjamin keamanan dan keutuhannya sampai saat diserahterimakan kembali kepada nasabah. Catatan-catatan terkait gadai KCA juga disimpan didalam tempat yang aman seperti lemari besi, agar memudahkan pengecekan. Perusahaan tidak memiliki peraturan khusus mengenai lamanya dokumen dan catatan harus disimpan atau dimusnahkan.

Pegadaian UPC Kaliwungu juga menyimpan file nasabah dan transaksi gadai KCA didalam database perusahaan. Pegadaian memiliki aplikasi penunjang transaksi gadai yang memuat file dan data nasabah, aplikasi tersebut dinamakan PASSION (Pegadaian Application Support System Integrated Online). Dengan adanya aplikasi ini akan membantu pengendalian fisik terhadap catatan maupun file-file yang ada. Untuk membuka aplikasi tersebut juga dibutuhkan password sehingga tidak sembarang orang dapat mengaksesnya.

5. Pemeriksaan independen atas kinerja

Kegiatan gadai KCA yang berlangsung di PT Pegadaian (Persero) Unit Pelayanan Cabang Kaliwungu selalu diperiksa dan diawasi oleh Pengelola UPC. Pemimpin cabang juga memiliki kewenangan untuk melakukan pemeriksaan terhadap aktivitas bisnis yang dilakukan oleh Pegadaian UPC Kaliwungu, dengan mendatangi kantor Unit Pegadaian. Pemeriksaan independen atas kinerja ini sudah diterapkan dengan baik oleh perusahaan.

\section{d. Informasi dan Komunikasi}

Tujuan sistem informasi dan komunikasi akuntansi dari perusahaan adalah untuk memulai, mencatat, memroses, dan melaporkan transaksi yang dilakukan. Pegadaian telah membangun sebuah sistem informasi online yang dinamakan PASSION, untuk membantu setiap transaksi dan pelaporan yang terjadi. Rekap transaksi per harinya dapat 
dilihat dengan jelas di aplikasi PASSION, laporan keuangan dan operasional dihasilkan dari transaksi PASSION tersebut. Dalam sistem pemberian kredit gadai KCA, pemberian informasi dan komunikasi sudah jelas diberikan kesetiap lini. Perusahaan juga secara berkala melakukan sosialisasi dan rapat untuk penyampaian berbagai informasi.

\section{e. Pemantauan}

Aktivitas pemantauan berhubungan dengan penilaian mutu pengendalian internal secara berkelanjutan atau periodik oleh manajemen untuk menentukan bahwa pengendalian itu telah beroperasi seperti yang diharapkan, dan telah dimodifikasi sesuai dengan perubahan kondisi. Pengelola UPC mengawasi dan memantau kegiatan yang terjadi pada unitnya setiap saat, karena pengelola UPC bertanggung jawab secara penuh terhadap unitnya.

Pemantauan dan pengawasan Pegadaian UPC Kaliwungu dilakukan oleh dua birokrasi yang ada, birokrasi pertama yaitu pemimpin cabang yang melakukan pengawasan secara melekat (WASKAT), dan tim auditor yang diturunkan langsung oleh PT Pegadaian (Persero). Pemantauan ini dilakukan minimal dua kali dalam setahun, yang dilakukan secara menyeluruh pada semua bidang, baik keuangan, kas, maupun kegiatan operasional. Perusahaan juga melakukan pemantauan melaui evaluasi kinerja yang dilakukan secara rutin disetiap unit kerja. Kegiatan pemantauan yang dilakukan perusahaan sudah dilakukan dengan baik dan terstruktur.

\section{SIMPULAN}

Berdasarkan pembahasan yang telah dipaparkan pada bab sebelumnya, berikut merupakan kesimpulan dari penelitian ini:

1. $\quad$ PT Pegadaian (Persero) Unit Pelayanan Cabang Kaliwungu telah menerapkan sistem pengendalian intern terhadap pemberian kredit dengan baik. Lima komponen pengendalian intern yang diterapkan yaitu lingkungan pengendalian, penilaian risiko, aktivitas pengendalian, informasi dan komunikasi, serta pemantauan. Komponen tersebut telah diterapkan dengan baik dibuktikan dengan dilakukannya pemantauan dan pengawasan secara menyeluruh terhadap aktivitas gadai KCA.

2. Komponen sistem pengendalian intern terhadap pemberian kredit pada PT Pegadaian (Persero) Unit Pelayanan Cabang Kaliwungu telah sesuai dengan komponen pengendalian menurut COSO (Committee of Sponsoring Organization). Kelima komponen pegendalian telah dijalankan dengan baik, namun pada beberapa komponen yaitu lingkungan pengendalian dan aktivitas pengendalian belum diterapkan secara memadai, sesuai dengan komponen pengendalian intern COSO. Seperti terjadinya rangkap jabatan yang dilakukan pada Pegadaian UPC Kaliwungu. Hal tersebut terjadi karena keterbatasan SDM yang dimiliki perusahaan.

Berdasarkan pembahasan dan hasil penelitian mengenai sistem pengendalian intern terhadap pemberian kredit pada Pegadaian UPC Kaliwungu, sebaiknya rangkap jabatan yang terjadi pada perusahaan harus dilakukan evaluasi kembali, agar lebih sesuai dengan tugas dan deskripsi awal. Dengan terbatasnya jumlah SDM yang ada, rangkap jabatan yang terjadi pada bagian penaksir yang dirangkap oleh Pengelola UPC masih bisa dikendalikan, karena mengingat efisiensi kerja. Selain itu risiko yang terjadi pada aktivitas gadai KCA seperti komplain nasabah karena kondisi fisik barang jaminannya, dapat diantisipasi dengan memberikan pemahaman kepada nasabah tentang kondisi barang jaminannya saat masuk dilengkapi dengan keterangan kondisi agunan di Surat Bukti Gadai, serta menjelaskan 
bahwa barang jaminan akan disimpan dengan baik digudang penyimpanan.

\section{DAFTAR PUSTAKA}

Alek dan Achmad. 2011. Bahasa Indonesia untuk Perguruan Tinggi. Jakarta: Kencana.

Arens. A Alvin, Randal J Elder, Mark S. Beasley. 2008. Auditing dan Jasa Assurance. Jakarta: Penerbit Erlangga.

Azwar, Saifuddin. 2010. Metode Penelitian. Yogyakarta: Pustaka Pelajar.

Bungin, M. Burhan. 2013. Metodologi Penelitian Sosial dan Ekonomi. Jakarta: Kencana Prenada Media Group.

Diana, Anastasia dan Lilis Setiawati. 2011. Sistem Informasi Akuntansi. Yogyakarta: Penerbit Andi.

Jusup, Al Haryono. 2001. Auditing. Yogyakarta: Bagian Penerbitan Sekolah Tinggi Ilmu Ekonomi YKPN.

Kitab Undang-Undang Hukum Perdata (Burgerlijk Wetboek voor Indonesie).

Krismiaji. 2015. Sistem Informasi Akuntansi. Yogyakarta: Sekolah Tinggi Ilmu Manajemen YKPN.

Mulyadi. 2013. Auditing. Jakarta: Salemba Empat.

Mulyadi. 2016. Sistem Akuntansi. Jakarta: Salemba Empat.

Narbuko, Cholid dan Abu Achmadi. 2008. Metodologi Penelitian. Jakarta: Bumi Aksara.

PT Pegadaian. 2019. Pegadaian. https://www.pegadaian.co.id/, (16 Januari 2019).

Putera, Andri Donnal. 2018. Sri Mulyani Senang dengan Hasil Survei Ekonomi Indonesia Versi
$O E C D$.

https://kilasdaerah.kompas.com/ jawa-

tengah/read/2018/10/10/1354303 26/sri-mulyani-senang-denganhasil-survei-ekonomi-indonesiaversi-oecd, (16 Januari 2019).

Republik Indonesia. 1998. UndangUndang Republik Indonesia Nomor 10 Tahun 1998 tentang Perubahan atas UndangUndang Nomor 7 Tahun 1992 tentang Perbankan. Jakarta.

Republik Indonesia. 2011. Peraturan Pemerintah Republik Indonesia Nomor 51 Tahun 2011 tentang Perubahan Bentuk Badan Hukum Perusahaan Umum (PERUM) Pegadaian menjadi Perusahaan Perseroan (Persero). Jakarta

Sugiyono. 2007. Metode Penelitian Kuantitatif Kualitatif dan $R \& D$. Bandung: Alfabeta.

Sugiyono. 2014. Memahami Penelitian Kualitatif. Bandung: Alfabeta.

Tim P3. 2014. Buku Pedoman Penyusunan Penelitian/Skripsi. Semarang: Politeknik Negeri Semarang.

Wikipedia. 2019. Pegadaian (perusahaan). https://id.wikipedia.org/wiki/Peg adaian_(perusahaan). (12 Juni 2019). 